European journal of American studies

\title{
Washington Crossing the Media: American Presidential Rhetoric and Cultural Iconography
}

Jutta Ernst

\section{OpenEdition}

\section{Journals}

Édition électronique

URL : https://journals.openedition.org/ejas/9527

DOI : 10.4000/ejas.9527

ISSN : 1991-9336

Éditeur

European Association for American Studies

Référence électronique

Jutta Ernst, «Washington Crossing the Media: American Presidential Rhetoric and Cultural Iconography », European journal of American studies [En ligne], 7-2 | 2012, mis en ligne le 03 avril 2012, consulté le 08 juillet 2021. URL : http://journals.openedition.org/ejas/9527 ; DOI : https://doi.org/ $10.4000 /$ ejas. 9527

Ce document a été généré automatiquement le 8 juillet 2021.

Creative Commons License 


\title{
Washington Crossing the Media: American Presidential Rhetoric and Cultural Iconography
}

\author{
Jutta Ernst
}

1 In American history, the Revolutionary War holds a central position. As a foundational moment it includes a strong mythical dimension and thus has been of prime importance to American self-perceptions and to the formation of its national identity. The war which, in due course, cut the ties with the British mother country and led to independence is deeply rooted in American cultural memory in the sense of shared experience and common knowledge about the people and its past. ${ }^{1}$ As acts of remembrance do not solely pertain to times gone by, but rather link an event from the past to the present, ultimately reconstructing the historical moment from a later perspective $^{2}$ in order to achieve "a usable past," "sthe outcome is a proliferation of different views giving us varying stories of the nation's beginning. But even if there are multiple and conflicting versions of origin, usually a standard repertoire for referring to one people's history develops, for here, too, just as in other cases of representation and mediation, processes of canonization are at work. Not surprisingly, in their speeches and written communications, the nation's leaders often rely on the most widely accepted cultural iconography to recall past events, drawing on both verbal and visual accounts as well as on performative reenactments that have been enshrined in the people's minds.

2 A time-honored, traditional discourse might, however, go together with the use of contemporary media technology as a means of distribution, as in the case of Barack obama. For not only did he make ample use of the Internet in his election campaign, he also launched "the first live Internet video chat by an American president" in March 2009. ${ }^{4}$ Framing Obama's rhetorical strategies within 19th- and 20th-century artistic representations of one specific historical moment from the Revolutionary War, I would like to contribute to an enlarged understanding of the intricate relations between politics, the arts, and media development and of the ways they appropriate the past. A 
short introduction to the historic event in question will be followed by a discussion of Obama's references to it. In a second part, I will present different artistic renderings, from the realm of painting and from the realm of poetry, that shed light on the current President's rhetorical choices.

The summer and fall of 1776 marked a low point for Commander-in-Chief George Washington and the Continental Army. They could not defend New York, lost Fort Washington and Fort Lee and were pushed back to Pennsylvania, where the fall of Philadelphia, the seat of the Continental Congress, had to be feared. ${ }^{5}$ In this seemingly desperate situation, Washington decided on an attack. On Christmas Eve 1776, he had his severely diminished regiment cross the Delaware and successfully assault a Hessian garrison at Trenton in the morning of December 26th. On January 3, 1777 the Continental Army defeated British troops at Princeton. According to legend, these two American victories brought a decisive turn in the War of Independence. ${ }^{6}$ The Revolution, which, in the eyes of many, had already faltered, ${ }^{7}$ gained new momentum and finally led to the well-known result: in the Treaty of Paris (1783) Great Britain accepted the colonies' independence and agreed to a retreat of the King's troops from American soil. ${ }^{8}$

5 Interestingly, it was not only Washington's triumph in a militarily difficult situation that made the crossing of the Delaware a milestone of American history and turned the General into a national hero. The disadvantageous weather conditions, which obstructed the operations, added to these effects. After a cold and clear day, it had started to rain, to hail, and to snow. A strong northeastern storm had set in, which produced dangerous floats of ice on the Delaware. ${ }^{9}$ The darkness of the night made the crossing even more perilous. For only if Washington's troops crossed the river unobserved and started a surprise attack before day break, was there a chance of success..$^{10}$ Despite a considerable loss of time and the failure of parts of the army to reach the Jersey shore, the General's plan succeeded in the end. Colonel Rall, commander of the Hessian troops at Trenton, had not believed that the "clod-hoppers," as he called the Americans, ${ }^{11}$ would venture an attack. ${ }^{12}$

6 Over the years, Washington's crossing of the Delaware River has been depicted and interpreted in many different ways. While British General William Howe, in his reports, held the Hessian mercenaries and their allegedly incompetent leaders responsible for the defeat at Trenton, the American loyalists felt that Howe himself had to take the blame, all the more so as he had not grasped the chance of completely destroying Washington's army..$^{13}$ What both readings have in common, though, is the downplaying of the role of Washington and his troops. These actors, however, usually stand in the center of American representations: George Washington is seen as a fighter for freedom and Republican ideals. ${ }^{14}$

7 It is not only historians who have recourse to Washington's crossing. Politicians, too, from Abraham Lincoln to Barack Obama, have referred to this event, thus illustrating the emblematic potential of this historical moment and the persistence of American presidential rhetoric. Lincoln stated in 1861, at the beginning of the American Civil War: "Of [Washington's] struggles none fixed itself on my mind so indelibly as the crossing of the Delaware preceding the battle of Trenton. I remember these great struggles were made for some object. I am exceeding anxious that the object they fought for - liberty, and the Union and Constitution they formed - shall be 
perpetual." ${ }^{15}$ Approximately 150 years later, George Washington and his deeds, at least as reported by popular legends, became a preferred point of reference for Barack Obama. As was hoped by Obama, the press started to equate the current U.S. President with the first. This is illustrated, for instance, by a cover photo from the New York regional magazine InsideOutHudson Valley and another one from The New Yorker, which both show Obama as a latter-day George Washington. ${ }^{16}$

My first example for an Obama reference to Washington's crossing stems from the 2008 Holiday Radio Address, which Obama, then President-elect, delivered to the nation: ${ }^{17}$

232 years ago, when America was newly born as a nation, George Washington and his Army faced impossible odds as they struggled to free themselves from the grip of an empire.

It was Christmas Day - December 25th, 1776 - that they fought through ice and cold to make an improbable crossing of the Delaware River. They caught the enemy off guard, won victories in Trenton and Princeton, and gave new momentum to a beleaguered Army and new hope to the cause of Independence.

Many ages have passed since that first American Christmas. We have crossed many rivers as a people. But the lessons that have carried us through are the same lessons that [...] guide us to this very day: that hope endures, and that a new birth of peace is always possible. ${ }^{18}$

9 At a time when the country was facing a severe economic crisis and was engaged in difficult military missions abroad, the nation, so Obama insinuates, had to emulate the virtues shown by Washington and his troops, that is, to be optimistic and active rather than lose confidence and give in to seemingly unfavorable circumstances. Courage was needed in the eyes of the President, belief and trust in the nation's abilities that were so aptly demonstrated, not only in 1776 , but time and again, as his earlier reference to "the unbroken line of heroism" and the phrase "We have crossed many rivers as a people" make clear. Past successful behavior thus becomes the benchmark for future action. Repeatedly employing the terms "new" and "hope" and expressing his conviction that "[...] a new birth of peace is always possible," Obama tries to make the nation anticipate better times, to see the chance for a fresh start, thereby adding a visionary quality to his Holiday Radio Address.

Obama mentions Washington's crossing again in an even more important speech, namely his Inaugural Address. The address is structured in such a way that the reference to Washington's crossing, which appears at a most prominent place at the very end, is gradually prepared for: having alluded to the "Declaration of Independence"19 and to "the risk-takers, the doers, the makers of things [...] who have carried us up the long rugged path towards prosperity and freedom," Obama closes as follows:

So let us mark this day with remembrance of who we are and how far we have traveled. In the year of America's birth, in the coldest of months, a small band of patriots huddled by dying campfires on the shores of an icy river. The capital was abandoned. The enemy was advancing. The snow was stained with blood. At the moment when the outcome of our revolution was most in doubt, the father of our nation ordered these words to be read to the people:

"Let it be told to the future world ... that in the depth of winter, when nothing but hope and virtue could survive ... that the city and the country, alarmed at one common danger, came forth to meet [it]."

America: In the face of our common dangers, in this winter of our hardship, let us remember these timeless words. With hope and virtue, let us brave once more the icy currents, and endure what storms may come. Let it be said by our children's 
children that when we were tested we refused to let this journey end, that we did not turn back nor did we falter; and with eyes fixed on the horizon and God's grace upon us, we carried forth that great gift of freedom and delivered it safely to future generations. ${ }^{20}$

11 As the initial phrase of this passage shows, Obama, in his attempt at assessing the current situation of the American nation, draws on past achievements and reminds of the progress that has been made ("remembrance," "how far we have traveled"). But references to earlier accomplishments not only serve as a means of explaining the present and of defining a collective identity ("who we are"); in a teleological fashion, they also allow for an outlook into the future. They help to construct a time which is as yet unsure and may thus be perceived as threatening by many people. Endowed with a design and purpose derived from the past, the future might appear less insecure and, in the end, more manageable. ${ }^{21}$ Among the pivotal historical moments with a stabilizing function, once again the events of Christmas 1776 loom large. George Washington is not mentioned by name but the term "the father of our nation" together with the phrase "the year of America's birth" leaves no doubt as to whom Obama refers. The crossing of the Delaware River, clearly indicated by "brave [...] the icy currents," is turned in this speech into an emblem for the perseverance of the American people in most adverse conditions. Interestingly, however, the words which Obama quotes in the final passage of his address, and which, as he says, "the father of our nation ordered [...] to be read to the people," are not Washington's own. They come from Thomas Paine's tract "The Crisis," which appeared on December 19, 1776 in the Pennsylvania Journal and which was reissued a few days later in the form of a pamphlet. ${ }^{22}$ The fact that the words in question are the quotation of a quotation reinforces the mythical and archetypal anchoring of Obama's speech.

12 In addition, Obama's Inaugural Address, in many different ways, harks back to the Bible and thus to a remote Christian past, the beginnings of which remain even more indeterminate. First of all, the idea of being "tested" recalls Abraham's experience with God, who asked him to sacrifice his only son. ${ }^{23}$ Secondly, "remembrance" is a central Biblical concern, as is apparent, for instance, from Jesus' words uttered with reference to the Eucharist: "[...] Take, eat: this is my body, which is broken for you: this do in remembrance of me." ${ }^{24}$ The same might be said for "hope" and "virtue," ${ }^{25}$ two key words in the quoted passage, that, together with the phrase "our children's children," 26 further support the religious tradition that Obama inscribes himself in. Stylistically, too, the Bible served obama as a source of inspiration. Paratactical syntax abounds in both the Bible and Obama's Inaugural Address as does the repetition of key words and the formula "let us." By recalling an important moment from the nation's past and linking it to Biblical contexts, Obama makes use of two rhetorical strands that, in American historical discourse, were often intertwined, thus broadening the basis of examples for possible future developments. A seemingly hopeless situation, both traditions teach, might not be the end but rather a new beginning.

Obama's references to Washington's crossing in his 2008 Holiday Radio Address and in his Inaugural Address, speeches which were directed to the whole nation, prove an important point: namely that Obama and his chief speech writer Jon Favreau ${ }^{27}$ started from the premise that the historical event the President alludes to is widely known. And it is, indeed, a moment deeply engrained in American memory. For Washington's crossing of the Delaware is among the historical moments that are extensively dealt with in high schools and colleges. However, not only lessons and history books are 
responsible for the general public's acquaintance with what happened on Christmas Eve 1776. Washington's crossing of the Delaware has inspired many artists and writers, who have contributed to making this event known, turning it into a truly popular moment whose function it is to create social belonging. Their repeated and often revisionary treatments of the subject will serve me in the following as a means of framing Obama's references.

The most famous visual rendering of Washington crossing the Delaware, which also finds itself on stamps, coffee mugs, and T-shirts, ${ }^{28}$ stems from the German-American Emanuel Gottlieb Leutze (1816-1868). Leutze, who, in the 1840s, had enrolled in the Düsseldorf Art Academy, was a liberal who tried to combine his political convictions with his artistic practice. ${ }^{29}$ This is illustrated, among other things, by his painting Washington Crossing the Delaware, which he started in Düsseldorf in the fall of $1849 . .^{30}$ Leutze's decision to embark on the representation of this event from the American past was, no doubt, triggered by its importance for the history of the United States. ${ }^{31}$ However, there is a second reason, closely linked to the contemporary situation in Germany. Since 1848, there had been political and social uproar in the German states, quarrels pro and con a united Germany with a democratic form of government. ${ }^{32}$ But when the National Assembly was dissolved (June 1849), the German revolutionaries lost hope. In this situation, Leutze's painting could have functioned as a psychological stimulus for the German population, rekindling the revolutionary spirit. In November 1850 , however, shortly before Leutze finished the painting, fire broke out in the artist's studio and severely damaged the canvas. Leutze started a second version, once again under the title Washington Crossing the Delaware. The second picture was shown in New York and Washington in late 1851 and early 1852 and evoked most positive commentaries in the press..$^{33}$ Today this painting belongs to the Metropolitan Museum of Art in New York City. ${ }^{34}$

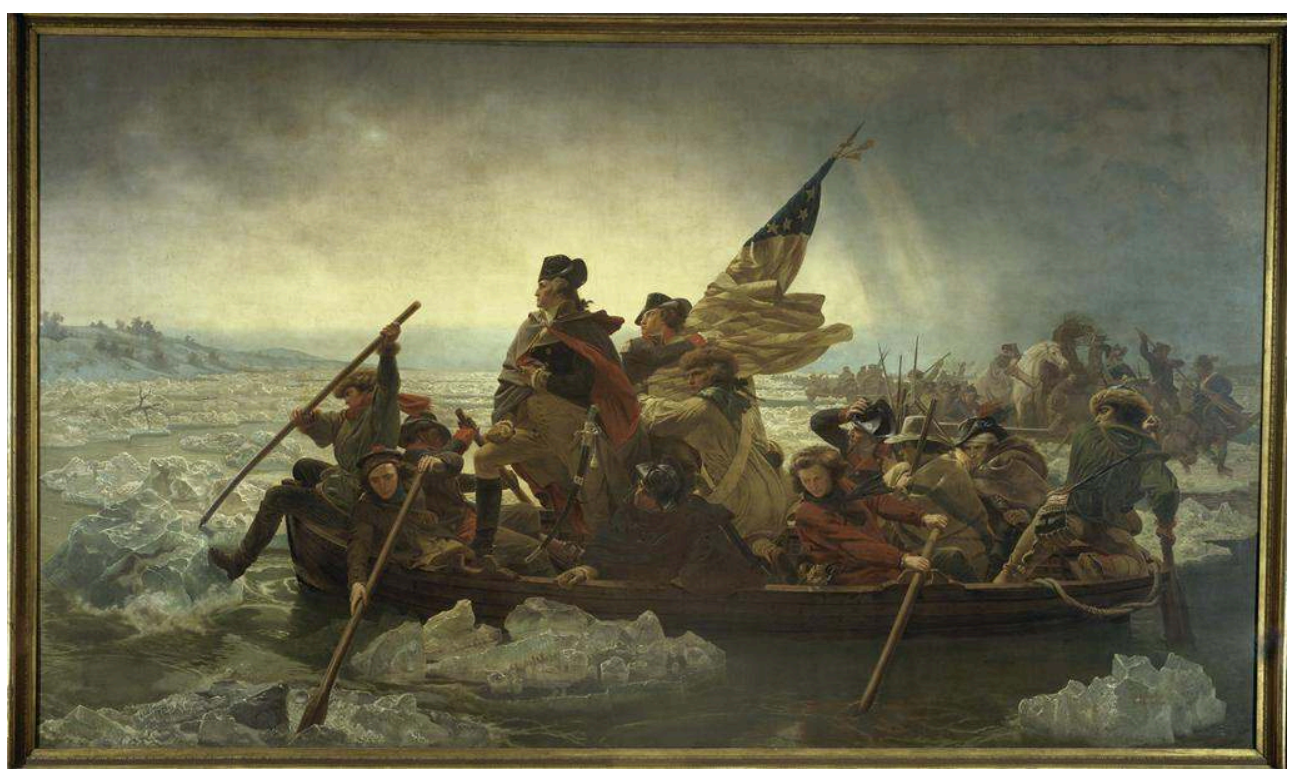

Leutze, Emanuel Gottlieb (1816-1868): Washington Crossing the Delaware, 1851. New York, The Metropolitan Museum of Art. Oil on canvas, $149 \times 255$ in. $(378.5 \times 647.7 \mathrm{~cm})$. Gift of John Stewart Kennedy, 1897. Acc. n.: 97. 34. Image@ The Metropolitan Museum of Art, New York.

Leutze's painting is rather simply and efficiently symbolical, stressing the diversity of the Americans, on the one hand, while underlining their common effort and their 
shared ultimate goal, on the other hand. In the foreground, the monumental canvas shows 13 figures, alluding to the 13 American states that had declared their independence. ${ }^{35}$ The majority of these figures represent types, but some are individualized historical persons. The people's outward appearance, both their clothing and their complexions, serve to indicate their different origins and their past experiences: farmers with big hats, who might come from Pennsylvania or New Jersey, a Western hunter in deerskin leggings, a seaman in a tarpaulin jacket, whose relatively dark complexion might point to his African descent. Another man is wearing a Balmoral bonnet and might therefore be identified as a Scottish immigrant. ${ }^{36}$

In the prow of the boat, a man in the uniform of the Continental Army is visible and a second one, who bears the American flag. They represent George Washington and Lieutenant James Monroe. ${ }^{37}$ Washington's role as General is indicated by his central position within the painting, but also by the way he is depicted: he is standing upright, towering above his fellow men, with one foot on the front bench of the boat, a posture that suggests a stepping forward and upward, for short, an advancement to a higher level. Washington appears in profile with a resolute facial expression, ${ }^{38}$ sure of what will await him, for there is no need to use the telescope which he holds in his right hand. With his eyes fixed on the New Jersey shore, he seems to fearlessly anticipate the future. Ultimately, Washington appears not only as the determined commander of the Continental Army, but also as the dignified statesman he was later to become.

Further details in Leutze's painting support this forging together of past, present, and future. Swords and guns document the troop's readiness to fight, once they will have reached the New Jersey shore. Conversely, the bandaged head of one soldier reminds of a previous battle, in the course of which members of the Continental Army had been wounded..$^{39}$ The unfavorable weather conditions on Christmas Eve 1776 are clearly discernible in the picture: the furled flag points to the storm, floats of ice are to be seen, and the sky is full of clouds. But even with respect to the meteorological elements of his painting, Leutze has transcended the present. In the upper left, a star is visible, which symbolically indicates hope for the future ${ }^{40}$ Leutze's, painting, then, contrary to its title, does not concentrate on the present, on the moment of crossing the Delaware River, but fuses different time levels and thereby creates a historical continuum.

Again and again, critics have pointed to obvious inaccuracies in Leutze's painting. Already in 1851, a commentator remarked:

The time is twilight, and the atmosphere hazy and snowy, corresponding with the record of history. [...] The river is very full, almost jammed, with floating ice, which perhaps may be subject to a slight remark of criticism. Such ice as is there represented could not have been in the river at that time of the year, (25th of December,) when the young and thin ice is forming. But the painting is a truthful and beautiful representation of ice suddenly broken up by a freshet in the spring of the year. Then the sturdy fellow sitting on the bow of the boat might in reality encounter an iceberg two or three feet thick which should defy his utmost efforts with his boathook. However, Mr. Leutze has given us excellent ice, and excellent water, and every way an excellent painting; and if spring ice was more effective for his purpose than the ice of autumn, perhaps a justifiable poetic licence would allow him to use it. ${ }^{41}$ troops could not have carried the flag shown in the picture, for it was only introduced in $1777,{ }^{42}$ counter the idea of a documentary effort on the part of Leutze, while 
supporting a reading of his painting in the sense of mythic beginnings and prolepsis of future developments.

The central idea of continuity and progress ${ }^{43}$ is enhanced by the perspective that Leutze chose for his painting. Whereas Washington and his men crossed the Delaware in a west-east direction, Leutze's pictorial representation, at least if one applies the conventions of mapping with the west being on the viewer's left and the east on his or her right, suggests that the boat is heading west. Given this spatial orientation, the crossing of the Delaware recalls the first settlers' voyage across the Atlantic, thereby underlining the emancipation from the British mother country ${ }^{44}$ and, with Washington stepping upward, the establishment of a superior nation in the New World. Leutze's painting, then, draws on diverse watershed moments of American history and, in a synthetic fashion, illustrates both the mythic origin of the U.S.A. and their potential for renewal. Through the inclusion of the star, which might be interpreted as a reference to the Biblical legend of the three Magi, ${ }^{45}$ Leutze, moreover, makes the course of American history appear as God's providential plan.

Interestingly, the symbolic import of Leutze's painting is not limited to the U.S.A. It hints at the idea of civilizatory advancement in a more general fashion, all the more so as, in art and cultural history, humanity's progress has usually been depicted as a westward movement. ${ }^{46}$ The following lines by the Irish philosopher and writer George Berkeley (1685-1753) illustrate this very clearly:

Westward the course of empire takes its way;

The four first Acts already past,

A fifth shall close the Drama with the day;

Time's noblest offspring is the last. ${ }^{47}$

Washington's crossing of the Delaware is thus turned into an event which is not only central to American history, but to the history of mankind.

In 1953, the American artist Larry Rivers (1923-2002) took up Leutze's subject and produced a history painting with exactly the same title: Washington Crossing the Delaware. 


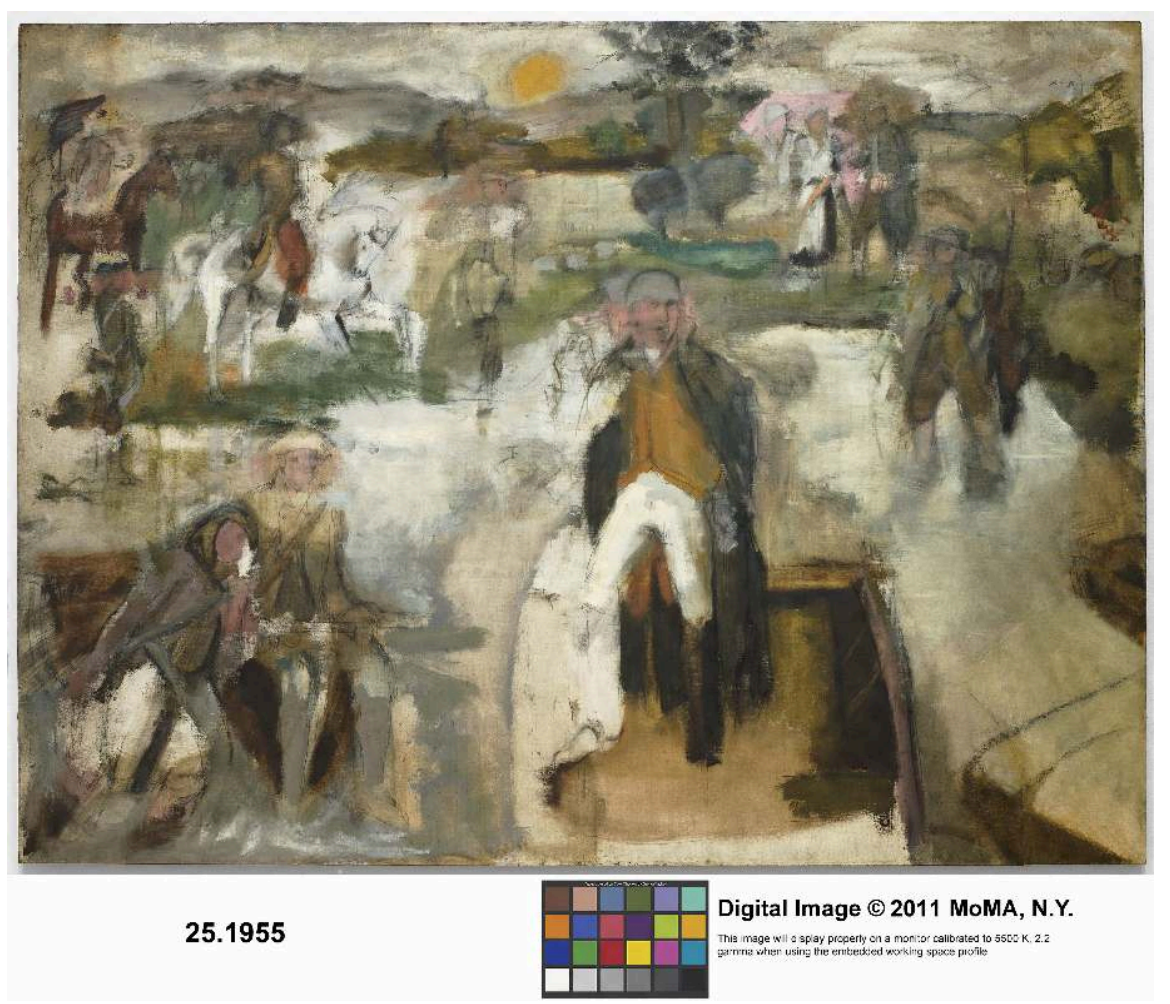

Rivers, Larry (1923-2002): Washington Crossing the Delaware, 1953. New York, Museum of Modern Art (MoMa). Oil, graphite, and charcoal on linen, 6' 11 5/8' x 9' 3 5/8' $(212.4 \times 283.5 \mathrm{~cm})$. Given anonymously. Acc. n.: 25. 1955. (c) 2012. Digital image, The Museum of Modern Art, New York/Scala, Florence; VG Bild-Kunst, Bonn.

In contrast to Leutze's painting, where the Americans form a compact group, the human figures in the Rivers painting are relatively isolated, with Washington dominating in the center. The outlines of persons and objects are blurred; they appear incomplete and two-dimensional like "sketchy versions of children's book illustrations," ${ }^{48}$ so that it is hard for the viewer to assess the whole scene. Ultimately, it is only the title of the painting which allows to identify the represented event as Washington's crossing of the Delaware. Whereas Leutze gave an ex post facto representation of the historical moment, depicting Washington's crossing with a conscious reference to events set in the future and thereby glorifying it, Rivers places the viewer in medias res, showing the crossing from the perspective of the participants, who severely suffered and could not be sure of a victory at Trenton. Rivers' own statement clearly supports this thesis:

The last painting that dealt with George and the rebels is hanging in the Met and was painted by a coarse German nineteenth-century academician named Leutze who really loved Napoleon more than anyone and thought crossing a river on a late December afternoon was just another excuse for a general to assume a heroic, slightly tragic pose. [...] What I saw in the crossing was quite different. I saw the moment as nerve-wracking and uncomfortable. I couldn't picture anyone getting into a chilly river around Christmas time with anything resembling hand-on-chestheroics. ${ }^{49}$

What is also revealed here is the revisionary impulse behind Rivers' work of art: his painting calls into question the national founding myth which Leutze's picture built upon and helped to perpetuate. In Rivers' version, George Washington neither appears as the courageous hero nor his crossing as a great feat. The General, though depicted in 
a larger scale than the other figures,${ }^{50}$ is a static participant in a dubious venture, the outcome of which lies in the dark. The lack of hat or wig marks him as an ordinary, private figure rather than as a national icon. ${ }^{51}$ In addition, as Raphael J. Schulte argues, "[...] the angle of his boat suggests a movement downward, as if sinking." ${ }^{52}$ In the end, however, Rivers substitutes one myth for another, for his "post-modern Washington" is just as much removed from the historical person than Leutze's. ${ }^{53}$

Larry Rivers, an important transitory figure between Abstract Expressionism and Pop $\mathrm{Art}^{54}$ who, at the high time of McCarthyism, fashioned his version of Washington Crossing the Delaware with the contemporary political situation in the U.S.A. in view, ${ }^{55}$ had close ties to John Ashbery, Kenneth Koch, Frank O'Hara and other New York poets. ${ }^{56}$ With O'Hara (1926-1966), who also was an art critic and later worked as curator of the Museum of Modern Art in New York City, ${ }^{57}$ Rivers started a fruitful artistic collaboration across different media. A prominent example is O'Hara's poetic response to Larry Rivers' Washington Crossing the Delaware: in 1955, he published the poem "On Seeing Larry Rivers' Washington Crossing the Delaware at the Museum of Modern Art." Rather than as a traditional example of ekphrasis, O'Hara's poem can be regarded as the author's attempt to adopt painterly techniques, to achieve with words what Rivers accomplished with paint and brush. ${ }^{58}$ Most importantly, he, too, challenges the hackneyed representations of George Washington and his crossing of the Delaware. The first stanza of the poem is very telling in this respect:

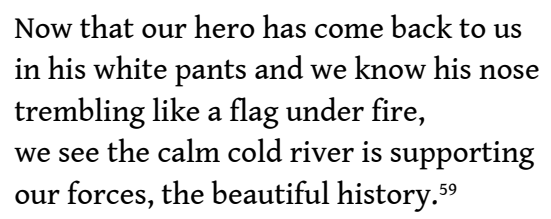

O'Hara's poem sets in with the completion of a memorial process which has brought back to the present ("Now") a figure from the past. The commemorative act is a communal one, for the speaker uses personal pronouns in the plural form ("our," "us," "we"). "[o]ur hero," "a flag," "the [...] cold river", "our forces," and "the beautiful history" serve to recall the well-known national narrative of Washington's passage across the Delaware. But some of those phrases, given the context in which they are used, undermine that very tale. The flag, for instance, is only a simile indicating the intensive trembling of Washington's nose. As a possible sign of nervousness, this detail undercuts the idea of Washington as a hero and stresses his average humanity instead. A similar turnaround is noticeable with regard to the natural element of the river. Whereas in the most frequently cited version of the legend, Washington and his troops had to battle against the floats of ice and could reach the New Jersey shore only thanks to their hardihood, O'Hara characterizes the Delaware as "calm" and supportive of the Continental Army, thereby further reducing Washington's role as brave Commanderin-Chief.

Throughout the poem, the "[d]ear father of our country," as he is ironically addressed in stanza four, is demythologized and reinvented, a process which reaches its climax at the very end: "Don't shoot until, the white of freedom glinting / on your gun barrel, you see the general fear." The last two words may not only be understood in the sense of 'the fear of the public' but also in the sense of 'General Washington shows fear.' This pun adds to the depiction of Washington as a contradictory figure, a figure, which is ultimately revealed as a fiction. ${ }^{60}$ The colloquial, irreverent style of the poem stands in stark contrast to the epic topic and plays its part in freeing a historical figure from 
stock connotations ${ }^{61}$ The total effect is one of indeterminacy, a blurring of meanings, quite similar to the effect of Larry Rivers' canvas. ${ }^{62}$

As a work of art which refers to a painting that is based on an earlier painting which reconstructs and necessarily interprets a crucial moment from the Revolutionary War, O'Hara's poem aptly stresses the futility of attempts at authentic representation. ${ }^{63}$ There is no original point in the past that could be captured and objectively fixed. There are only layers of rhetoric and iconography that stylize a mythic beginning according to the needs of the present.

This also holds true for Obama's 2008 Holiday Radio Address and his Inaugural Address. In a moment of crisis, Obama reminds of past achievements, of victory and progress, and projects these into the future with the help of traditional rhetoric and cultural iconography. He prolongs the myth of Washington crossing the Delaware, even if he uses the latest media technology to do so. Ultimately, his plea: "[...] let us brave once more the icy currents, and endure what storms may come" ${ }^{64}$ is a more elaborate version of his election campaign slogan: "Yes, we can," highlighting the American potential for recommencement.

\section{NOTES}

1. See Jan Assmann, who defines cultural memory as "that body of reusable texts, images, and rituals specific to each society in each epoch, whose 'cultivation' serves to stabilize and convey that society's self-image. Upon such collective knowledge, for the most part (but not exclusively) of the past, each group bases its awareness of unity and particularity." Jan Assmann, "Collective Memory and Cultural Identity," trans. John Czaplicka, New German Critique 65 (Spring-Summer 1995): 132.

2. Cf. Astrid Erll, "Literatur als Medium des kollektiven Gedächtnisses," in Gedächtniskonzepte der Literaturwissenschaft: Theoretische Grundlegung und Anwendungsperspektiven, ed. Astrid Erll and Ansgar Nünning (Berlin: de Gruyter, 2005), 252.

3. Van Wyck Brooks, “On Creating a Usable Past," Dial 64, no. 764, 11 April 1918, 339.

4. Sheryl Gay Stolberg, "Obama Makes History in Live Internet Video Chat," New York Times, 27 March 2009, http://www.nytimes.com/2009/03/27/us/politics/27obama.html.

5. David Bonk, Trenton and Princeton, 1776-77: Washington Crosses the Delaware (New York: Osprey, 2009), 44; John Ferling, Almost a Miracle: The American Victory in the War of Independence (Oxford: Oxford University Press, 2007), 156, 161; and David Hackett Fischer, Washington's Crossing (Oxford: Oxford University Press, 2004), 10.

6. Paul S. Boyer, Clifford E. Clark, Jr., Joseph F. Kett, Neal Salisbury, Harvard Sitkoff, and Nancy Woloch, eds., The Enduring Vision: A History of the American People. 6th ed. (Boston: Houghton Mifflin, 2008), 163; Ferling, Almost a Miracle, 178; and Fischer, Washington's Crossing, 5, 142-143.

7. Ferling, Almost a Miracle, 186; Fischer, Washington's Crossing, 117, 137, 363.

8. Boyer et al., Enduring Vision, 169.

9. Bonk, Trenton and Princeton, 48.

10. Fischer, Washington's Crossing, 219.

11. Bonk, Trenton and Princeton, 49. 
12. Ferling, Almost a Miracle, 175-176.

13. Fischer, Washington's Crossing, 426-427.

14. Ibid., 428 .

15. Quoted in ibid., 438.

16. Cover. InsideOut Hudson Valley, November-December 2008, http://www.insideouthv.com/ Cover_NovDec08.jpg; Cover. New Yorker, 26 January 2009, http://www.newyorker.com/magazine/ toc/2009/01/26/toc.

17. A video clip of this speech can be accessed on YouTube.

18. Barack Obama, "Holiday Radio Address," 24 December 2008, http://www.cbsnews.com/ 8301-503544_162-4685856-503544.html.

19. Apart from the term "our founding documents" the following phrase in Obama's address is pertinent: "The time has come to reaffirm our enduring spirit; to choose our better history; to carry forward that precious gift, that noble idea passed on from generation to generation: the God-given promise that all are equal, all are free, and all deserve a chance to pursue their full measure of happiness." Barack Obama, "Inaugural Address," 20 January 2009, http:// www.whitehouse.gov/blog/inaugural-address/. Cf. Thomas Jefferson, "A Declaration by the Representatives of the United States of America, in General Congress Assembled," in The Life and Selected Writings of Thomas Jefferson, ed. Adrienne Koch and William Peden (New York: Random House, 1972), 22.

20. Obama, "Inaugural Address."

21. As Michiko Kakutani convincingly argues in The New York Times, "[t]alking of the continuum of history enables Mr. Obama to remind us of the progress that has been made toward perfecting this nation, and this Enlightenment faith in progress, in turn, offers the hope that today's challenges, too, can be met and conquered [...]." Michiko Kakutani, "Speech Puts a New Frame on Obama's Call to Serve," New YorkTimes, 20 January 2009, http://www.nytimes.com/2009/01/21/ us/politics/21kakutani.html?fta =y.

22. Thomas Paine, The Writings of Thomas Paine, ed. Moncure Daniel Conway, vol. 1, http:// www.gutenberg.org/files/3741/3741-h/3741-h.htm; Ferling, Almost a Miracle, 169; Fischer, Washington's Crossing, 141.

23. The King James Bible,http://www.gutenberg.org/files/10/10-h/10-h.htm, Gen. 22: 1-19.

24. Ibid., 1 Cor. 11: 24.

25. See, for instance, ibid., Rom. 8: 24 and 2 Pet. 1: 3.

26. This phrase is used, for example, in ibid., Ps. 103: 17.

27. Eli Saslow, "Helping to Write History," Washington Post, 18 December 2008, http:// www.washingtonpost.com/wp-dyn/content/article/2008/12/17/AR2008121703903.html.

28. Fischer, Washington's Crossing, 4.

29. Barbara S. Groseclose, Emanuel Leutze, 1816-1868: Freedom Is the Only King (Washington, DC: Smithsonian Institution Press, 1975), 16, 29.

30. Ibid., 34, 83. Leutze's painting was neither the first nor the last depicting this pivotal moment of American history, as Thomas Sully's The Passage of the Delaware (1819), Edward Hicks' Washington Crossed Here (c. 1833), George Caleb Bingham's Washington Crossing the Delaware (1856-71), and Robert Colescott's George Washington Carver Crossing the Delaware: Page from an American History Textbook (1974-75), among others, prove. For a comparison of some these representations see Karsten Fitz, "Contested Space: Washington Crossing the Delaware as a Site of American Cultural Memory," in Space in America: Theory, History, Culture, ed. Klaus Benesch and Kerstin Schmidt (Amsterdam: Rodopi, 2005), 561-575.

31. Leutze owned two publications in which this historic event is described, George Bancroft's History of the United States (1834-74) and J. Spark's Life of Washington (1829). Groseclose, Emanuel Leutze, $65 \mathrm{n} 31$.

32. Ibid., 30 . 
33. A commentator for The Literary World remarked, "We saw this painting under great disadvantages, it being set against the wall, without a frame, and in a bad position for light, but we are sure that the highly-wrought anticipations of the public will be more than realized. It is incomparably the best painting yet executed of an American subject. [...] It is abundantly varied in character, strong in color, and full of emphasis and earnestness without exaggeration." "Leutze's Washington Crossing the Delaware," Literary World, 18 October 1851, 311. Under the rubric "Editor's Correspondence," the Daily National Intelligencer published the following assessment: "Much of the strong interest excited by this painting is undoubtedly to be attributed to the subject. The artist has been happy in selecting a subject that comes home at once to the heart of every American, and powerfully stirs and kindles the patriotic sentiment. [...] But whatever, interest may attach to the subject, the handling and the execution of the artist are equally essential to the success of the work; and these, it appears to me, are such as to command success. [...] The whole landscape and perspective are admirably presented. [...] Such a work as the artist has given us deserves the gratitude of the country, as a worthy record of one of the most interesting incidents of our history, and as a stimulus to patriotism and love of the Union." Bird's-Eye, “Leutze's Washington Crossing the Delaware," Daily National Intelligencer, 26 November 1851, A.

34. Groseclose, Emanuel Leutze, 37-38, 40, 83n56.

35. The 13th person is hidden from sight, but his weapon is to be seen. Fischer, Washington's Crossing, 2.

36. Ibid., 1-2.

37. Ibid.

38. Groseclose, Emanuel Leutze, 34.

39. Fitz, "Contested Space," $564 \mathrm{n} 11$.

40. Fischer, Washington's Crossing, 2. Udo J. Hebel rightly calls Leutze's painting "the quintessential representation of George Washington's historical role as the larger-than-life epic hero leading the emerging U.S.-American nation into a bright future of glory and progress." Udo J. Hebel, "Sites of Memory in U.S.-American Histories and Cultures," in Cultural Memory Studies: An International Interdisciplinary Handbook, ed. Astrid Erll and Ansgar Nünning (Berlin: de Gruyter, 2008), 52.

41. Bird's-Eye, "Leutze's Washington," A.

42. In 1776, the Grand Union Flag was used, which fused the British Union Jack with thirteen stripes. Fischer, Washington's Crossing, 10.

43. See Truettner, who remarks, "Leutze apparently believed that history paintings were composed around important or 'clear' ideas that [...] enabled one to see history developing [...] toward well-defined, progressive goals. These ideas not only transcended time and place, but also drove a historical process that required each succeeding age to appear more enlightened than its predecessor." William H. Truettner, "Storming the Teocalli - Again; Or, Further Thoughts on Reading History Paintings," American Art 9, no. 3 (1995): 73.

44. Cf. Fitz, who identifies "the landing-theme" and "the rite de passage-motif" in Leutze's painting. Fitz, "Contested Space," 573-574.

45. Ibid., 569.

46. Ibid., 568-569, 572-573.

47. George Berkeley, "On the Prospect of Planting Arts and Learning in America," in Library of the World's Best Literature, Ancient and Modern, ed. Charles Dudley Warner, vol. 4, 1896, http:// www.gutenberg.org/files/13220/13220-h/13220-h.htm. In 1862, Leutze painted Westward the Course of Empire Takes Its Way for the United States Capitol in Washington, D.C. Truettner, "Storming the Teocalli," 70.

48. Suzanne Ferguson, “Crossing the Delaware with Larry Rivers and Frank O'Hara: The PostModern Hero at the Battle of Signifiers," Word \& Image 2, no. 1 (January-March 1986): 29. 
49. Quoted in Raphael J. Schulte, “Re-Imagining the 'Beautiful History': Frank O’Hara and Larry Rivers," Fu Jen Studies 32 (1999): 49.

50. Ferguson, "Crossing the Delaware," 30. Interestingly, David Hackett Fischer takes the "small eccentric figure, mounted on a prancing white horse in the upper left corner of the painting" as Washington. Fischer, Washington's Crossing, 453. Contradictory readings, such as the ones by Suzanne Ferguson and Fischer, clearly support the painting's indeterminacy.

51. Ferguson, "Crossing the Delaware," 30.

52. Schulte, "Re-Imagining," 50.

53. Ferguson, "Crossing the Delaware," 29.

54. Brad Gooch, City Poet: The Life and Times of Frank O'Hara (New York: Knopf, 1993), 238.

55. Schulte, "Re-Imagining," 48-49.

56. Carl Haenlein, Larry Rivers: Retrospektive - Zeichnungen (Hannover: Kestner-Gesellschaft, 1980), 19.

57. Lytle Shaw, Frank O'Hara: The Poetics of Coterie (Iowa City: University of Iowa Press, 2006), 118.

58. Michael Davidson, "Ekphrasis and the Postmodern Painter Poem," Journal of Aesthetics and Art Criticism 42, no. 1 (Autumn 1983): 71-72; Helen Koriath, Larry Rivers:Bildende Kunst in Beziehung zur Dichtung Frank O'Haras (Frankfurt a.M.: Lang, 1990), 100, 105.

59. Frank O'Hara, The Selected Poems of Frank O'Hara, ed. Donald Allen (New York: Knopf, 1974), 101.

60. Davidson, "Ekphrasis," 73.

61. Cf. Shaw, Frank O'Hara, 34.

62. David L. Sweet, “Parodic Nostalgia for Aesthetic Machismo: Frank O'Hara and Jackson Pollock," Journal of Modern Literature 23, no. 3-4 (Summer 2000): 386.

63. See Davidson, "Ekphrasis," 72; John Lowney, "The 'Post-Anti-Esthetic' Poetics of Frank O'Hara," Contemporary Literature 32, no. 2 (Summer 1991): 247.

64. Obama, "Inaugural Address."

\section{RÉSUMÉS}

The Revolutionary War has been of prime importance to American self-perceptions and to the formation of its national identity. As a foundational moment with a strong mythical dimension it has become a cherished point of reference for the nation's leaders, who, in their speeches and written communications, rely on the most widely accepted cultural iconography to recall this event. A time-honored, traditional discourse might, however, go together with the use of contemporary media technology as a means of distribution, as in the case of Barack Obama. Framing Obama's rhetorical strategies within 19th- and 20th-century artistic representations of one specific historical moment from the Revolutionary War, Washington's crossing of the Delaware river, this paper seeks to contribute to an enlarged understanding of the intricate relations between politics, the arts, and media development and of the ways they appropriate the past 
INDEX

Keywords : American Painting, Cultural Iconography, Holiday Radio Address, Inaugural Address, Presidential Rhetoric, Revolutionary War

\section{AUTEURS}

JUTTA ERNST

Johannes Gutenberg-Universität, Mainz 